\title{
Shipping Firms' Efficiency Evaluation through Stochastic Frontier Analysis
}

\author{
Dimitris Gavalas \\ Shipping, Trade \& Transport Department, Business School, University of Aegean, Chios, Greece \\ Email:dgaval@aegean.gr
}

Received 26 April 2016; accepted 25 July 2016; published 28 July 2016

Copyright (C) 2016 by author and Scientific Research Publishing Inc.

This work is licensed under the Creative Commons Attribution International License (CC BY). http://creativecommons.org/licenses/by/4.0/

(c) (i) Open Access

\section{Abstract}

The concept of this study is to note whether financial risk assessment tools impact a shipping firm's performance, competitiveness and efficiency. Stochastic Frontier Analysis (SFA) is used in the evaluation of such issues. The shipping industry has been classified in three segments, namely dry bulk, tankers (including LPG and LNG) and containers. The influence of the risk assessment indicators on market and operational efficiency is subsequently determined by using a panel regression. This assists to determine whether different asset allocation and risk management techniques improve the performance of shipping firms. Our sample consists of 82 international shipowning firms drawn from Bloomberg database for the period of 2001-2014. Through estimating efficiency, our model shows that containerized cargo firms have better performance in market and operating efficiency as well.

\section{Keywords}

Financial Risk, Assessment Tools, Stochastic Frontier Analysis, Shipping Industry

\section{Introduction}

Since the credit crunch of the last quinquennium, firms across the shipping industry have been seeking for alternative sources of business financing. An increasing stream of firms have entered into the stock market through IPOs or the secondary market to raise the appropriate amount of cash to run their off-shore businesses and operate their vessels. The firm from the one hand needs to raise money to invest, but from the other hand investors need to make sure that the indices of the firm are reliable of its financial situation. One might say that indices have grown more powerful. That might be partly because of the growth of passive index investing, in which funds follow an index, being a positive development since it reduces costs. Costs are the best single predictor of the future performance of an investment that a firm would prefer to follow. If fund managers assume that the 
firm's performance compared to the index performance will determine whether investors give their money, then the index will naturally be of high importance for their decisions. To diverge from the benchmark would risk for a possible underperformance and investors taking away their funds.

Shipping IPOs are different from those of ordinary industrial or service companies. The market value of a shipping company is often closely related to the value of the vessels. This means that shipping IPOs function in a similar way to the respective IPOs of funds and property companies. Furthermore, due to wide intelligence in S \& P shipping markets worldwide, shipping IPOs tend to exhibit lower information asymmetry [1]. Shipping has a clear cyclical nature; thus shipping companies tend to prefer equity markets when prospects seem to be auspicious.

Throughout the review of existing literature one may find that researchers have come up with the concept of efficiency to assess performance. As found in [2], when one refers to performance of shipping companies, this means either financial performance (ratios used in accounting) or overall efficiency (distributions of inputs). Actually, what characterizes an effective manager is the ability to foresee the risks ahead and establish an early warning signal strategy to mitigate the potential risks concerning financial performance and the overall efficiency of the shipping firm.

The crucial issue that we try to shed light on in this paper is whether indeed an early warning signal strategy is capable of affecting the firm's market and operating efficiency. We reckon that the study closer to ours is that of [3], to which we mainly differ in the sample (82 against 79 firms), the period studied (2001-2014 against 20012010) and the variables used in the model. Our study is divided into two parts: the first one includes the efficiency measurement model driven from [3] and [4] and in the second part we run a panel regression to check the influence of various financial strategies upon the performance of shipping firms. Listed shipping firms have been categorized into three segments that are dry bulk, tankers (including LPG and LNG) and containers. The method to classify each firm to one of the three segments is by discriminating the main activity of the firm. Financial data stem from Bloomberg database, while the firms in our sample do not stop short at ship-owning firms, but also at ship-managers and charterers. Thus we could underpin that our sample expressed the global shipping listed directory. The efficiency evaluation is implementing via the stochastic Frontier Analysis (SFA).

The remaining part of paper is structured as follows. In Section 2, the literature review on efficiency studies is revealed. We proceed with Section 3 presenting the methodology used in this study. In Section 4, the SFA and panel regression are implement in terms of empirical analysis. We conclude in Section 5.

\section{Methodology and Data Analysis}

The work of [5] initiated the deep analysis of frontiers and efficiency measurement. This study provided definitions and a computational framework for both "technical and allocative efficiency". Based on Farrell's work, the measurement of efficiency and the way to estimate frontiers have developed enormously over the past decades. In this respect, Data Envelopment Analysis (DEA) and Stochastic Frontier Analysis (SFA) are the two most important alternative approaches; both approaches have been broadly studied as methodologies in their own right and applied to a range of business contexts.

SFA assumes that a parametric function exists between production inputs and outputs [6] and [7]. As an alternative approach to DEA, the great virtue of SFA is that it not only allows for technical inefficiency, but also acknowledges the fact that random shocks outside the management of producers can affect the output production. For this reason, the essential idea behind SFA is that the error term is composed of two parts; a one-sided component that captures the effects of inefficiency relative to the stochastic frontier, as well as a symmetric component that permits random variation of the frontier across the firms' sample, and captures the effects of measurement error, other statistical noise, and random shocks outside the firm's management. In this occasion, the SFA (cross-sectional) has been used and a panel stochastic frontier model as well.

\subsection{Revealing the SFA}

Production frontier models indicate the maximum production capacity a firm can produce given the available resources. To what extent a firm deviates from the production possibility frontier is actually the measurement tool for inefficiency. This method seems better than the ordinary least squared (OLS) regression because firms may fall short of the production frontier but cannot go beyond it. Additionally, symmetric distribution around the production frontier cannot be assured as in OLS. Apart from [6] and [7] seen before, more recently [8] pro- 
vided a further detailed explanation.

In this study, we assume that each firm produces less than its optimal output due to a degree of inefficiency. Specifically, $Y_{i t}=f\left(X_{i t} ; \beta\right) \xi_{i t}$, where $Y_{i t}$ and $X_{i t}$ are the appropriate forms of output and the combination of inputs respectively in the production function with $i$ denoting shipping companies and $t$ denoting time. From the other hand, $\xi_{i t} \in(0,1]$ is the level of technical efficiency. Adding the stochastic components to the model, production function is subject to random and factors that may not be controlled. These effects are described by $\exp \left(v_{i t}\right)$. Equation (1) shows the above information:

$$
Y_{i t}=f\left(X_{i t} ; \beta\right) \xi_{i t} \exp \left(v_{i t}\right)
$$

where $i=1,2, \cdots, N, t=1,2, \cdots, T$.

If equation above is being logged, then Equation (2) is produced:

$$
\ln Y_{i t}=\beta_{0}+\sum \beta_{k} \ln x_{k}+v_{i t}-u_{i t},
$$

where $u_{i t} \equiv-\ln \xi_{i t}$

\subsection{Dataset}

The Bloomberg database has been the feeder for the shipping firm-level financial data used in this study. There have been several occasions where multiple observations have been found to exist within the same year. To front this situation, we proceeded to data cleansing, in order for the data set to be consistent with other similar data sets in the sample. Actually, original filings have been put aside and restated financial data has been ultimately used as inputs. There is no actual way of revealing the actual information and remove the "noise" but this has proved to be our best option. After data cleansing a series of 33 dry bulk, 31 tanker (incl. LPG \& LNG) and 18 container shipping companies have been included in the study. The series covers the period from 2000 to 2014.

The variables that have been used in the efficiency test are denoted in Table 1 . The enterprise value (ENTV) denotes the market efficiency of the shipping company, while sales (NS) represent the operating efficiency.

Accordingly, Table 2 shows the descriptive status of these variables. What may be extracted is that on average, the highest enterprise value and sales appear into the containerized market. As expected the leader of the market (in our case the containers) demand the most of capital expenditure (CAPEX) to face the challenges and the largest amount of full-time employees (FEMP) to manage such operations.

\section{Applying the Stochastic Frontier Analysis}

In this section the cross-sectional study is executed. Our sample of 82 shipping companies ${ }^{1}$ covers dry bulk, tanker and containers sectors. Afterwards, a panel data analysis is applied from 2000 to 2014 to observe the dynamics of the shipping industry. The period that has been chosen captures a whole shipping cycle.

\begin{tabular}{cc} 
Table 1. Definition of variables. & \\
\hline Variable & Definition \\
\hline TOTA & Total assets \\
TOTE & Total equity \\
$E B$ & EBITDA \\
$N S$ & Net sales \\
GRPR & Gross profit \\
ENTV & Enterprise value \\
CAPEX & Capital expenditure \\
FEMP & Full-time employees \\
\hline
\end{tabular}

Note: Table 1 describes the variables in our study. NS denotes the dependent variable for operating efficiency and ENTV for market efficiency.

\footnotetext{
${ }^{1}$ The sample covers 82 shipping companies, 30 of which are described as Greek owned, specified either by the stakeholders-owners of the company or by the geographical headquarters.
} 
Table 2. Descriptive statistics.

\begin{tabular}{|c|c|c|c|c|}
\hline Variable & Whole market & Containers & Dry bulk & Tankers \\
\hline \multirow[t]{2}{*}{ TOTA } & 3118.55 & 8323.88 & 912.12 & 1422.09 \\
\hline & $(6772.12)$ & $(11,332.11)$ & (1211.42) & $(1732.21)$ \\
\hline \multirow[t]{2}{*}{ TOTE } & 1211.93 & 2711.34 & 418.21 & 512.30 \\
\hline & (2722.17) & (4711.41) & (426.59) & $(521.42)$ \\
\hline \multirow[t]{2}{*}{$E B$} & 418.27 & 1052.11 & 131.11 & 162.67 \\
\hline & (1278.10) & (2144.78) & (132.78) & $(211.56)$ \\
\hline \multirow[t]{2}{*}{ NS } & 2256.12 & 6722.90 & 631.67 & 482.11 \\
\hline & (6156.89) & $(10,224.78)$ & (1162.71) & $(617.52)$ \\
\hline \multirow[t]{2}{*}{$G R P R$} & 832.18 & 2563.16 & 144.12 & 218.96 \\
\hline & $(4622.71)$ & (8772.14) & (152.46) & $(246.78)$ \\
\hline \multirow[t]{2}{*}{ ENTV } & $226,611.21$ & $553,119.73$ & $176,221.07$ & $12,771.22$ \\
\hline & $(864,221.70)$ & $(991,662.46)$ & $(822,162.26)$ & $(32,618.03)$ \\
\hline \multirow[t]{2}{*}{ CAPEX } & -281.38 & -611.72 & -152.45 & -172.72 \\
\hline & (527.19) & (962.11) & (182.13) & (182.19) \\
\hline \multirow[t]{2}{*}{ FEMP } & 3522 & 11,552 & 611 & 1179 \\
\hline & $(12,773)$ & $(22,183)$ & (822) & (2001) \\
\hline
\end{tabular}

Note: Table 3 shows the descriptive statistics of key variables (in USD mn., apart from FEMP estimated in number of persons). The coefficients denote the means and inside the parentheses one may see the standard deviations.

\subsection{Cross-Sectional \& Panel Frontier Models}

To set our model, we have followed [3] and [4]. In order to evaluate market efficiency of a shipping firm, the stochastic frontier model is formed as:

$$
\ln \operatorname{ENTV}_{i t}=\beta_{0}+\beta_{1} \ln G R P R_{i t}+\beta_{2} \ln T O T E_{i t}+v_{i t}-u_{i t} .
$$

We assume that the market value of a firm $i$ at time $t(E N T V)$ is related in a positive way to the profit of the firm $(G R P R)$ and its total equity (TOTE). $v_{i t}$ denotes the random error term, while $u_{i t}$ shows inefficiency. In order to evaluate operating performance efficiency of a shipping firm, the stochastic frontier model is formed as:

$$
\ln N S_{i t}=\beta_{0}+\beta_{1} \ln \text { TOTA }_{i t}+\beta_{2} \ln C A P E X_{i t}+\beta_{3} \ln F E M P_{i t}+v_{i t}-u_{i t} .
$$

Equation (4) depicts the correlation of the sales of a firm $i$ at time $t(N S)$ with the total assets (TOTA), capital expenditure (CAPEX) and the number of employees (FEMP). Table 3 presents the results of a cross-sectional study, where the signs are as expected. When a shipping firm has the capacity to raise equity and make profit, then its market value raises. On the other hand, the number of employees and the firm's assets lead to larger net sales.

It is possible that several factors affect a shipping firm's ability to reach the highest production frontier, where the output gap equals zero. As seen in Table 4, the results show that whether inefficiency is time-invariant or time-varying, there seems to be a consistency. Specifically, profit and equity are positively related to market efficiency; assets and number of full-time employees are positively related to operating performance efficiency, but negatively related to capital expenditure.

Table 5 shows the efficiency scores of the three main shipping segments. What seems clear is that high profit margins lead to high scores (on average) in market and operating efficiency for the firms in the containers market.

After observing the results our conclusions seem consistent with [3]. The scores from market efficiency evaluation are smaller than the ones obtained from the operating performance panel frontier model. In agreement with the previous researchers, in order to predict the enterprise value of a shipping firm, one may need macro 
Table 3. Frontier model-cross-sectional.

\begin{tabular}{|c|c|c|c|c|c|}
\hline \multicolumn{4}{|c|}{$\ln E N T V$} & \multicolumn{2}{|c|}{$\ln N S$} \\
\hline (A) & Half normal & Truncated normal & (B) & Half normal & Truncated normal \\
\hline \multirow[t]{2}{*}{$\ln G R P R$} & 0.154 & 0.153 & $\operatorname{lnTOTA}$ & 1.082 & 1.082 \\
\hline & $(0.412)$ & $(0.403)$ & & $(0.136)^{* * *}$ & $(0.136)^{* * *}$ \\
\hline \multirow[t]{4}{*}{ InTOTE } & 0.823 & 0.823 & $\operatorname{lnCAPEX}$ & -0.019 & -0.019 \\
\hline & $(0.442)^{*}$ & $(0.442)^{*}$ & & $(0.055)$ & $(0.055)$ \\
\hline & & & $\operatorname{lnFEMP}$ & 0.247 & 0.247 \\
\hline & & & & $(0.053)^{* * *}$ & $(0.053)^{* * *}$ \\
\hline \multirow[t]{2}{*}{ Cons } & 1.877 & 1.863 & Cons & -2.286 & -2.293 \\
\hline & (2.519) & (1.922) & & $(0.736)^{* * *}$ & $(0.727)^{* * *}$ \\
\hline Obs & 78 & 80 & Obs & 63 & 63 \\
\hline$\lambda$ & 0.011 & 0.012 & $\lambda$ & 0.025 & 0.031 \\
\hline$\sigma_{v}^{2}$ & 5.318 & 5.318 & $\sigma_{v}^{2}$ & 0.381 & 0.381 \\
\hline$\sigma_{\mu}^{2}$ & 0.001 & 0.001 & $\sigma_{\mu}^{2}$ & 0.000 & 0.000 \\
\hline
\end{tabular}

Note: Panel (A) present market efficiency and Panel (b) present operating performance efficiency. Standard errors have been put in parentheses. ${ }^{* * *}$, ${ }^{* *}$, ${ }^{*}$ are significant at $1 \%, 5 \%, 10 \%$ level.

Table 4. Frontier model-panel.

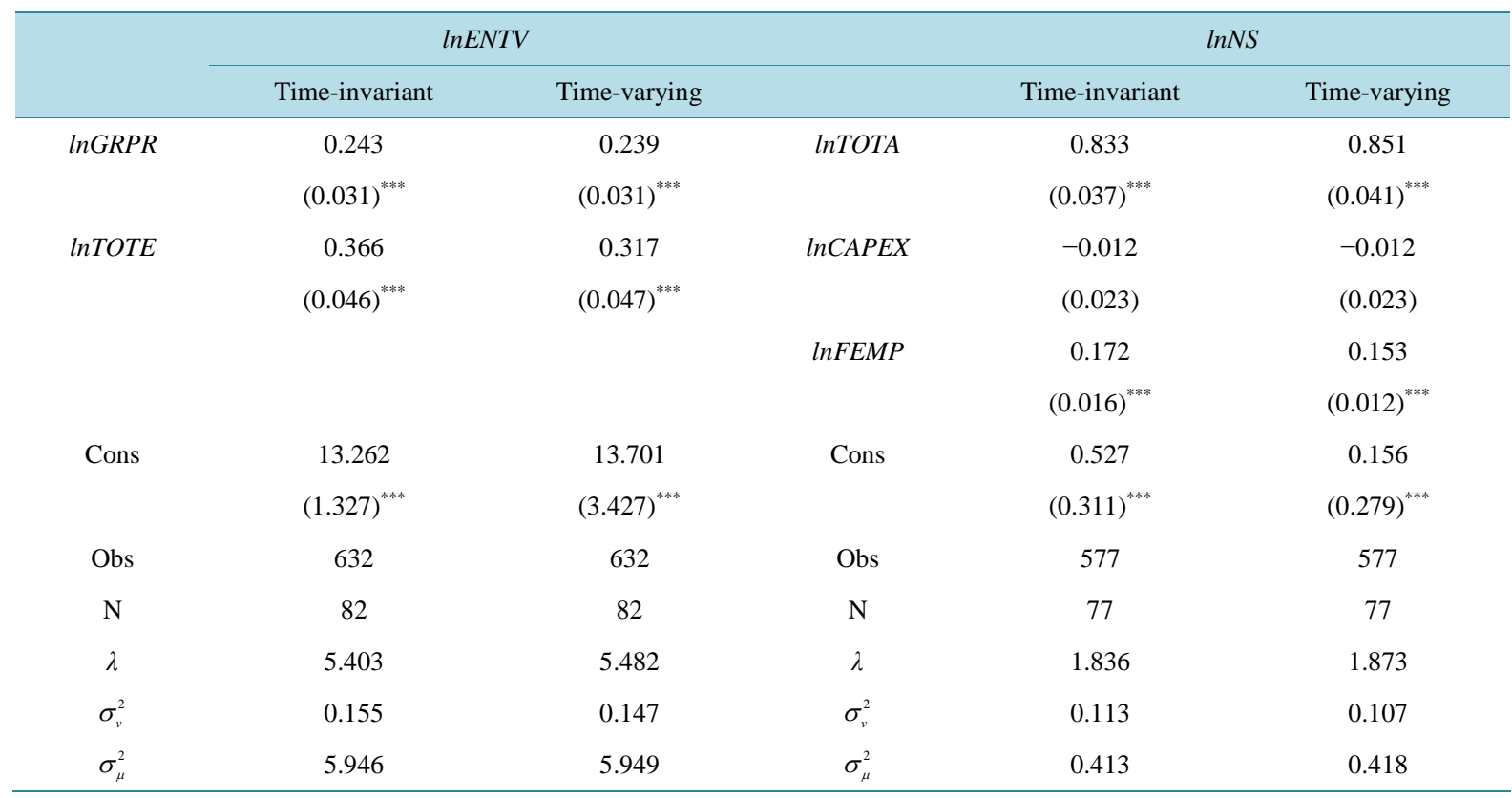

Note: Panel (A) present market efficiency and Panel (b) present operating performance efficiency. Standard errors have been put in parentheses. ${ }^{* * *}{ }^{* *}$, * are significant at $1 \%, 5 \%, 10 \%$ level.

data, shipping cycle data and perhaps credit rating details [9]-[11].

\subsection{Risk Exposure \& Early Warning System}

In a commonly agreed volatile environment, shipping firms experience business, physical and technical risks. However, in this study we focus on the financial perspective which directly affects the firm's performance. According to [12] financial risks in the shipping sector could be classified as default, credit, market, financial and 
liquidity. Each category can be quantified by the indicators defined in Table 6. The philosophy behind this structure is the CAMEL rating system.

In the 1980s, the US supervisory authorities were the first to establish "on-site examinations" ratings for banking institutions. This was done by using the CAMEL rating system and is used by all three US supervisory agencies, i.e. the Federal Reserve System, Office of the Comptroller of the Currency and the Federal Deposit Insurance Corporation [13]. The concept is based on examiner assessment of a banking institution under specific criteria on supervision. Specifically, each credit institution is evaluated on the basis of five critical component factors, relating to its operations and performance. These are Capital, Asset Quality, Management, Earnings and Liquidity [14].

Table 6 includes the risk assessment tools that could be the incorporated as efficiency determinants. After having gathered the results (relative efficiency scores) for market and operational efficiency, the risk management perception is being incorporated in the empirical model.

Moreover, Table 7 reports the descriptive statistics of above key variables.

After examining Table 7, it is deriver that containerized cargo shipping companies perform the greatest current liabilities ratio, and thus, the lowest current ratio and quick ratio. These firms need to gain access to the capital market instruments, in order to meet the demand for short-term cash flow. Furthermore, shipping firms operating in the tanker segment rely rather on the long-term debt to preserve plane operation, and thus, have the highest debt to asset ratio or perform a high leverage.

Table 5. Panel regression-efficiency scores.

\begin{tabular}{cccccc}
\hline & \multicolumn{2}{c}{ Market efficiency } & \multicolumn{2}{c}{ Operating efficiency } \\
\hline (A) & Time-invariant & Time-varying & (B) & Time-invariant & Time-varying \\
\hline Dry bulk & 0.037 & 0.012 & Dry bulk & 0.481 & 0.362 \\
& $(0.153)$ & $(0.062)$ & & $(0.266)$ & $(0.269)$ \\
Tankers & 0.002 & 0.001 & Tankers & 0.371 & 0.211 \\
& $(0.010)$ & $(0.004)$ & & $(0.217)$ & $(0.065)$ \\
Containers & 0.074 & 0.012 & Containers & 0.721 & $(0.524$ \\
& $(0.212)$ & $(0.037)$ & & $0.256)$ & $(0.142)$ \\
All & 0.034 & 0.012 & All & 0.431 & $(0.253)$ \\
\hline
\end{tabular}

Note: Means of efficiency scores. Standard deviations have been put in parentheses.

Table 6. Risk assessment tools.

\begin{tabular}{|c|c|c|}
\hline$A R T$ & Accounts receivable turnover & Net credit sales/average accounts receivable \\
\hline$I T$ & Inventory turnover & Cost of goods sold/average inventory \\
\hline$A P T$ & Accounts payable turnover & Total supplier purchases/average accounts payable \\
\hline TAT & Total assets turnover & Sales or revenues/total assets \\
\hline FAT & Fixed assets turnover & Net sales/Net property, plan \& equipment \\
\hline OET & Operating expense ratio & Property's operating expense/gross operating income \\
\hline ROI & Return on investment & (Gain of investment-cost of investment)/cost of investment \\
\hline$A C P$ & Average collection period & $\begin{array}{l}\text { (number of working days * average amount of accounts receivables)/total } \\
\text { amount of net credit sales during period }\end{array}$ \\
\hline$A P P$ & Average payment period & $\begin{array}{c}\text { (number of working days * average amount of accounts payable)/total } \\
\text { amount of net credit purchases during period }\end{array}$ \\
\hline
\end{tabular}

Note: The variables listed here denote ones that could serve as an early warning system of the shipping industry's exposure. 
Table 7. Risk assessment tools-descriptive statistics.

\begin{tabular}{|c|c|c|c|c|}
\hline Variable & Dry bulk & Tankers & Containers & All \\
\hline \multirow[t]{2}{*}{$A R T$} & 1.778 & 1.521 & 0.988 & 1.672 \\
\hline & (2.672) & (1.622) & (1.167) & $(1.722)$ \\
\hline \multirow[t]{2}{*}{$I T$} & 1.256 & 1.278 & 1.289 & 1.267 \\
\hline & (1.377) & (1.325) & (1.421) & (1.354) \\
\hline \multirow[t]{2}{*}{$A P T$} & 0.892 & 0.822 & 0.811 & 0.829 \\
\hline & (1.182) & (1.217) & (1.267) & (1.184) \\
\hline \multirow[t]{2}{*}{ TAT } & 2.143 & 1.866 & 2.142 & 2.054 \\
\hline & (2.213) & (1.874) & (2.211) & (2.147) \\
\hline \multirow[t]{2}{*}{$F A T$} & 2.441 & 2.318 & 2.114 & 2.410 \\
\hline & (2.499) & (2.345) & (2.154) & $(2.412)$ \\
\hline \multirow[t]{2}{*}{ OET } & 0.084 & 0.081 & 0.086 & 0.082 \\
\hline & $(0.085)$ & $(0.084)$ & $(0.087)$ & $(0.086)$ \\
\hline \multirow[t]{2}{*}{$R O I$} & 13.276 & 6.227 & 9.562 & 9.225 \\
\hline & (365.172) & (101.226) & (20.121) & (233.901) \\
\hline \multirow[t]{2}{*}{$A C P$} & 45 & 43 & 42 & 47 \\
\hline & (46) & (43) & (43) & (47) \\
\hline \multirow[t]{2}{*}{$A P P$} & 43 & 41 & 42 & 44 \\
\hline & (43) & (42) & (43) & (45) \\
\hline
\end{tabular}

Note: Table 7 reports the descriptive statistics of key risk assessment tools for the period 2000-2014. Standard deviations have been put in parentheses.

\section{Conclusions}

In this study, we evaluate operating and market efficiencies with financial outputs using SFA. Furthermore, we investigate determinants of the efficiency performance in terms of risk management in relation to financial strategies of international ship-owning firms. The results of panel SFA show that containerized cargo firms perform better than dry bulk and tanker firms in both market and operating efficiency models.

This study produces mixed results compared to the cross-sectional study by [4], but similar to the same study and [3] as well, containerized cargo firms seem more efficient in operating performance. From 2001 to 2014 our study's results showed that containerized cargo firms outperformed dry bulk and tanker firms. Moreover, containers firms require more employees, greater fixed investment, and more capital expenditure than the other sectors.

The panel results show that container firms perform a little bit to some extent better than tanker firms in the stock markets. When talking about efficiency determinants, it seems that risk management is more effective in explaining operating efficiency than in predicting market efficiency. Furthermore, liquidity is crucial to the industry which operates in a highly volatile market with a high rate of fixed cost.

\section{References}

[1] Syriopoulos, T. (2007) Financing Greek Shipping: Modern Instruments, Methods and Markets. In: Pallis, A., Ed., Maritime Transport: The Greek Paradigm, Research in Transportation Economics, 21, 171-219. http://dx.doi.org/10.1016/S0739-8859(07)21006-6

[2] Panayides, P.M., Gong, X.H. and Lambertides, N. (2010) Measuring Business Performance in Shipping. In: Grammenos, C., Ed., Handbook of Maritime Economics and Business, 2nd Edition, LLP, London, 625-655.

[3] Wang, G.W.Y., Woo, S.H. and Mileski, J. (2014) The Relative Efficiency and Financial Risk Assessment of Shipping Companies. Maritime Policy \& Management, 41, 651-666. 
[4] Panayides, P.M., Lambertides, N. and Savva. C.S. (2011) The Relative Efficiency of Shipping Companies. Transportation Research Part E: Logistics and Transportation Review, 47, 681-694. http://dx.doi.org/10.1016/j.tre.2011.01.001

[5] Farrell, M.J. (1957) The Measurement of Productive Efficiency. Journal of Royal Statistical Society, 120, $253-281$. http://dx.doi.org/10.2307/2343100

[6] Aigner, D., Lovell, C. and Schmidt, P. (1977) Formulation and Estimation of Stochastic Frontier Production Function Models. Journal of Econometrics, 6, 21-37. http://dx.doi.org/10.1016/0304-4076(77)90052-5

[7] Meeusen, W. and van den Broeck, J. (1977) Efficiency Estimation from Cobb-Douglas Production Functions with Composed Error. International Economic Review, 18, 435-444. http://dx.doi.org/10.2307/2525757

[8] Kumbhakar, S. and Lovell, C.A.K. (2000) Stochastic Frontier Analysis. University Press, Cambridge. http://dx.doi.org/10.1017/CBO9781139174411

[9] Gavalas, D. and Syriopoulos T. (2013) Bank Loan Quality and Credit Risk Exposure: A Multi-Criteria Decision Approach to Collateral Selection in shipping. Economics World, 1, 59-86.

[10] Gavalas, D. and Syriopoulos, T. (2014) Bank Credit Risk Management and Rating Migration Analysis on the Business Cycle. International Journal of Financial Studies, 2, 122-143. http://dx.doi.org/10.3390/ijfs2010122

[11] Gavalas, D. and Syriopoulos, T. (2014) Bank Credit Risk Management and Migration Analysis; Conditioning Transition Matrices on the Stage of the Business Cycle. International Advances in Economic Research, 20, 1-16. http://dx.doi.org/10.1007/s11294-014-9459-y

[12] Alizadeh, A.H., Kappou, K., Tsouknidis, D. and Visvikis, I. (2015) Liquidity Effects and FFA Returns in the International Shipping Derivatives Market. Transportation Research Part E: Logistics and Transportation Review, 76, 58-75. http://dx.doi.org/10.1016/j.tre.2015.02.001

[13] Sahajwala, R. and Van den Bergh, P. (2000) Supervisory Risk Assessment and Early Warning Systems. Basle Committee on Banking Supervision.

[14] Oet, M.V., Ong, S.J. and Gramlich, D. (2013) Policy in Adaptive Financial Markets—The Use of Systemic Risk Early Warning Tools. Federal Reserve Bank of Cleveland, Working Paper No. 1309.

Submit or recommend next manuscript to SCIRP and we will provide best service for you:

Accepting pre-submission inquiries through Email, Facebook, LinkedIn, Twitter, etc.

A wide selection of journals (inclusive of 9 subjects, more than 200 journals)

Providing 24-hour high-quality service

User-friendly online submission system

Fair and swift peer-review system

Efficient typesetting and proofreading procedure

Display of the result of downloads and visits, as well as the number of cited articles

Maximum dissemination of your research work

Submit your manuscript at: http://papersubmission.scirp.org/ 